\title{
Performance Analysis of Primary School Physical Education Teacher in Sibolga Post Taking Teacher Competence Test 2015
}

\author{
Roiman Dolok Tarsisius Situmorang \\ Sports Education \\ Postgraduate School UNIMED \\ Medan, Indonesia \\ roimansitumorang@gmail.com
}

\author{
Albadi Sinulingga \\ Sports Education \\ Postgraduate School UNIMED \\ Medan, Indonesia
}

\author{
Nurhayati Simatupang \\ Sports Education \\ Postgraduate School UNIMED \\ Medan, Indonesia
}

\begin{abstract}
This study aims to analyze the performance of Primary School Physical Education (PJOK) teachers in Sibolga who took the 2015 Teacher Competency Test scores below the national minimum completeness score of 41 people and above the minimum national completeness score totaling 16 people. This research is a quantitative study using a descriptive approach. The data collection method used is a survey method. The instruments used were observation sheets, and document reviews. Based on the results of data analysis, it is found that the average performance of PJOK teachers both those who obtained the Teacher Competency Test 2015 below the minimum national completeness score and those who scored above the national minimum completeness score was in the unfavorable category. Therefore, concrete efforts need to be made to improve the performance of elementary school PJOK teachers in Sibolga.
\end{abstract}

Keywords- physical education, teacher competence, teacher performance

\section{INTRODUCTION}

Sports and Health Physical Education (PJOK) is a field of study that has the same goals as other fields of study, namely in terms of achieving national education goals and must be implemented both at the level of primary education and at secondary education. However, PJOK has a different purpose specifically from other fields of study. Therefore, it is necessary to strive for various ways so that the learning objectives of PJOK can be achieved well and in accordance with what is expected. In achieving the goals of PJOK, there are many factors that influence and one of the factors that can influence is the level of teacher competency. Teachers who have good competence will have a positive effect on learning.

In general, the type of competency of Physical Education and Sports (PJOK) teachers is the same as other subject teachers as mandated in the Republic of Indonesia Government Regulation number 19 of 2005 concerning National Education Standards Chapter VI Educators and Education Personnel Standards Article 28 paragraph 3. In the Republic of Indonesia Government Regulation number 19 of 2005 concerning National Education Standards Chapter VI Educators and Education Personnel Standards article 28 paragraph 3 , it is written that the competence of each teacher in carrying out his duties as a learning agent at the level of primary and secondary education and early childhood education includes 4 competencies basic, namely; pedagogic, personal, professional and social competencies [4]. However, for PJOK teachers there is a slight difference from teachers in other fields of study, namely in professional competence.

Based on the Republic of Indonesia Government Regulation number 19 of 2005 concerning National Education Standards Chapter VI Educators and Education Personnel Standards article 28 paragraph 3 , it can be concluded that every teacher including PJOK teachers in carrying out their duties as learning agents must have good basic competencies, both in competence pedagogic, personality, social, and professional. By having a good level of competence, presumably PJOK teachers can show good performance as well. PJOK teachers who have good performance will make a positive contribution to the achievement of educational goals in general, and the goals of PJOK in particular. In this case it can be concluded that there is a correlation between teacher competency and teacher performance.

Speaking of performance, we should first understand what is meant by performance. The Big Indonesian Online Dictionary by the Ministry of Education and Culture (KEMDIKBUD) of the Republic of Indonesia states that the meaning of the word performance is something that is achieved, achievements shown, work ability (about equipment). On this occasion, the subject that will be discussed is about teacher performance. Supardi (2014: 54), states that teacher performance is the ability of a teacher in carrying out learning tasks and is responsible for students by increasing students' learning achievement [5].

In accordance with the demands of the Law of the Republic of Indonesia number 14 of 2005 concerning Teachers and Lecturers, Regulation of the Minister of National Education of the Republic of Indonesia number 16 of 2007, and Government Regulation of the Republic of Indonesia number 74 of 2008 , every teacher in the field of study including PJOK teachers must have a competency level that is good, both in pedagogical, personal, social, and professional competencies [1] [2] [3], so that the task as a learning agent 
can be carried out well. However, in reality what happened was not as expected.

Based on observations to the Sibolga City Education Office, 41 out of 57 teachers of Physical Education Sports and Health (PJOK) who taught at Primary Schools in Sibolga City did not pass the minimum limit value, which was 55 on the 2015 Teacher Competency Test (UKG) which held by the Ministry of Education and Culture (KEMDIKBUD). That is, only 16 people graduated and more Physical Education and Sports (PJOK) teachers who taught at the elementary school level in Sibolga City were not competent in the pedagogic and professional fields [6]. The data does not yet describe the level of teacher competency holistically as mandated in Law of the Republic of Indonesia number 14 of 2005 concerning Teachers and Lecturers, Regulation of the Minister of National Education of the Republic of Indonesia number 16 of 2007, and Government Regulation of the Republic of Indonesia number 74 of 2008 that each teachers must have good competence in four areas of competence, namely: pedagogical, personal, social, and professional competencies.

Presumption with the level of competence of teachers of Physical Education Sports and Health (PJOK) Elementary School (SD) in Sibolga City that will affect the performance as a learning agent. If the performance of PJOK teachers is low, the Teaching and Learning Activities (KBM) Physical Education and Health (PJOK) activities will not be implemented properly, so that it will hamper the achievement of the learning objectives of Physical Education and Sports (PJOK) activities themselves. Therefore, to prove the presumption that is true or false, it is necessary to make a concrete effort and lead to the existing problems. One concrete step to answer that presumption is to do research.

The purpose of this research is to find out the performance of Physical Education Sports and Health (PJOK) Primary Schools teachers in Sibolga City who scored beyond the minimum completeness limit of 2015 Teacher Competency Test (UKG) and the performance of Physical Education Sports and Health (PJOK) Primary Schools teacher in Sibolga City who scored below the minimum completeness limit of 2015 Teacher Competency Test (UKG).

\section{METHOD}

Respondents to be examined are the Physical Education and Physical Education teachers in elementary schools in Sibolga City. The population is 57 people. Because the respondents that will be used consist of two categories, namely teachers with UKG scores below the minimum completeness limit of 41 people and teachers with UKG scores above the minimum completeness limit of 16 people, the sampling technique used is cluster sampling.

Therefore, the respondents used were two groups namely; (a) Physical and Sports Physical Education teachers in Primary Schools (SD) in Sibolga City who have Teacher Competency Test scores below the minimum completeness limit, as many as 41 people, and (b) Physical and Sports Physical Education teachers in Primary Schools (SD) in the city of Sibolga which has a UKG value above the minimum completeness limit of 16 people.

The form of this research is a descriptive study using a quantitative approach. The approach used is quantitative, which uses data in the form of numbers as a tool to analyze information about what you want to know. The variable in this study is a single variable, namely teacher performance.

To collect data about the performance level of PJOK elementary school teachers in Sibolga City, the observation and documentation methods were used. The type of data collection instruments used in this study were non-test instruments. For the method of collecting data by observation, the data collection instrument used was an observation sheet containing an observation guide and a suitable list (checklist) and for the method of collecting data with documentation, the instrument used was a cook list and a table.

Teacher performance data that has been obtained using the observation method with instruments in the form of observation sheets (observations) are calculated using the formula:

$$
\text { rinalscore }=\frac{\sum n R+n L+n E}{\sum N} x i v 0
$$

$\mathrm{nR}$ : total value of Learning Planning

$\mathrm{nL}$ : total acquisition value of Learning Implementation

$\mathrm{nE}$ : total acquisition value of the Implementation of Process Evaluation and Learning Outcomes

$\mathrm{N}$ : total aspects assessed

Teacher performance data obtained using the match list instrument calculated using a formula:

$$
\text { Final Score }=\frac{\text { total documents completed }}{\text { total documents checked }} \times 100
$$

To analyze the teacher's performance data, both the data obtained from the observation sheet instrument and the checklist (checklist), descriptive data analysis techniques were used, namely by classifying the data into two groups namely qualitative and quantitative data. Qualitative data is expressed in the form of words or categories as in Table 1.

TABLE 1 SCORE AND CATEGORY OF THE PERFORMANCE

\begin{tabular}{|c|c|c|}
\hline No & Score & Category \\
\hline 1 &.$>80 \%$ & Very good \\
\hline 2 & $61 \%-80 \%$ & Good \\
\hline 3 & $41 \%-60 \%$ & Fair \\
\hline 4 & $21 \%-40 \%$ & Poorly \\
\hline 5 & $\leq 20 \%$ & Not good \\
\hline
\end{tabular}

While quantitative data is data in the form of numbers. For quantitative data calculated using the percentage technique with the following formula:

$$
P=\frac{f}{\pi} \times 100 \%
$$


P: percentage

$\mathrm{F}$ : the frequency that is being sought

$\mathrm{n}$ : total number of frequencies

\section{RESULT}

From the results of the assessment of the performance of PJOK teachers who received teacher competency test scores below the minimum completeness value on a national scale of 41 people, only 1 person scored in either category. Then, the results of the assessment of the performance of PJOK teachers who received teacher competency test scores above the minimum completeness value on a national scale of 16 people, only 2 people who scored in either category.

\section{DISCUSSION}

The low level of performance of elementary school PJOK teachers in the city of Sibolga after participating in the 2015 teacher competency test, both for teachers who received teacher competency test scores below the minimum completeness score and those who received teacher competency test scores above the minimum completeness score were caused by several factors, that is: (a) They don't want to keep learning to improve the abilities they already have. (b) Lack of facilities and infrastructure, such as; books, the internet, or other learning resources that they can use to improve the abilities they already have. (c)They are comfortable in the current situation.

\section{CONCLUSION}

Based on the data in the discussion section, it can be concluded that the level of performance of PJOK elementary school teachers in Sibolga City who received a teacher competency test score below the national minimum completeness score was in the low category. Likewise for elementary PJOK teachers in Sibolga City who received teacher competency test scores above the minimum completeness score nationally, their performance levels were also in the low category although there were some people who had good performance levels.

\section{REFERENCES}

[1] C. Umbara, Undang-Undang RI Nomor 14 Tahun 2005 \& Peraturan Pemerintah RI Nomor 74 Tahun 2008, Bandung: Citra Umbara, 2009.

[2] Peraturan Menteri Pendidikan Nasional Republik Indonesia Nomor 16 Tahun 2007.

[3] Peraturan Pemerintah Republik Indonesia Nomor 74 Tahun 2008.

[4] Peraturan Pemerintah Republik Indonesia nomor 19 tahun 2005

[5] Supardi, Kinerja Guru, Jakarta: PT RajaGrafindo Persada

[6] Kementerian Pendidikan dan Kebudayaan Republik Indonesia, Neraca Pendidikan Daerah Kota Sibolga, Jakarta, 2016 